1 Pelizzari E. Academic staff use, perception and expectations about open-access archives. A survey of social science sector at Brescia University. http:// eprints.rclis.org/archive/00000737/01/

Academic_staff_perception_about_Open_archives.htm (accessed 7 July 2004).

2 JISC/OSI. Journal authors survey report. www.jisc.ac.uk/uploaded documents/JISCOAreport1.pdf (accessed 7 July 2004).

3 Rowlands I, Nicholas D, Huntingdon P. Scholarly communication in the digital enviromment: what do authors want? Findings of an international survey of author opinion: project report. London: Centre for Information Behaviour and Evaluation of Research, Department of Information Science, City
University, 2004. http://ciber.soi.city.ac.uk./ciber-pa-report.pdf (accessed 7 July 2004).

4 Richardson M, Saxby C. Experimenting with open access publishing. Nature 2004. www.nature.com/nature/focus/accessdebate/12.html (accessed 7 July 2004).

5 Cozzarelli NR, Fulton KR, Sullenberger DM. Results of a PNAS author survey on an open access option for publication. Proc Natl Acad Sci 2004;101:1111. www.pnas.org/cgi/doi/10.1073/pnas.0307315101 (accessed 7 July 2004).

(Accepted 19 October 2004)

doi $10.1136 /$ bmj.38359.695220.82

\title{
Commentary: Open access publishing: too much oxygen?
}

\author{
Jeffrey K Aronson
}

"We hold these truths to be self-evident..." This assertion of the US founding fathers betokened their zeal for human equality and rights. But such an attitude can betoken intellectual arrogance. It was, for example, self evident to paediatricians in the 1950s that it would be beneficial to give premature babies $100 \%$ oxygen without proper trial. But $100 \%$ oxygen caused blindness, and the balance of benefit to harm was unfavourable.

In their survey of the attitudes of a small sample of scientists to open access ${ }^{1}$ Schroter and colleagues don't actually trumpet its self evident benefits, but their call for evidence refers to the author pays model, not open access publishing itself, although open access will not be possible without an author pays scheme or something comparable. But scientists' opinions should not frame policy without supporting evidence. We need to ask whether immediate free access to readers, with whatever method of payment is used, would benefit science (not the scientists or the grant giving bodies, who are also zealous about this idea) and hence society. To zealots ("the dream is now achievable") the benefits of this $100 \%$ oxygen may be self evident. But we have little evidence about the balance of benefits and harms. I believe that the potential advantages are few and the disadvantages many; I have summarised them on bmj.com.

Why should we uncritically adopt this system? We already have a better one, operated by many journals currently and in increasing numbers, in which readers pay for immediate access and access becomes universally free after a delay, for example 12 months, as required by the National Library of Medicine and the Wellcome Trust in their current initiative to digitise back issues of journals. Schemes such as HINARI (Health InterNetwork Access to Research Initiative) and AGORA (Access to Global Online Research in Agriculture) will maximise opportunities to access material that is published in this way. ${ }^{3}$

In any system the burden of cost should be spread across those who are advantaged. A mixed model might be appropriate, maintaining subscriptions while allowing authors who want or are forced to pay for immediate free access to pay for it, and those who do not want it or cannot afford it, not to. Currently, some journals adopt author pays access, others do not. But there are many more readers than authors, which any balance in funding should reflect.

The uncritical application of basic values is a major source of unforeseen undesirable consequences of social actions. ${ }^{4}$ Who doesn't instinctively feel that free access on day one is basically desirable? But we need to be completely sure that if we open the tap on the cylinder of this $100 \%$ oxygen the benefit to harm balance will be favourable, for we will not be able to turn the tap off-there will be no way back to subscription based journal publishing. As the third author of the above paper ${ }^{1}$ has written elsewhere, "think harm always."

Competing interests: JKA is a fellow of the British Pharmacological Society and chairman of the editorial board of the British Journal of Clinical Pharmacology, which is published on the society's behalf by Blackwell Publishing, as a subscription journal with free access after 12 months; the complete archives of the journal are about to be digitised for free access.

Schroter S, Tite L, Smith R. Perceptions of open access publishing: interviews with journal authors. BMJ 2005;330:756-9.

2 Delamothe T, Smith R. Open access publishing takes off. The dream is now achievable. $B M J$ 2004;328:1-3.

Katikireddi SV. HINARI: bridging the global information divide. BMJ 2004;328:1190-3.

Merton RK. The unanticipated consequences of purposive social action. Am Sociol Rev 1936;1:894-904.

Smith R. Think harm always [editor's choice]. BMJ 2004;329. (3 July.)

A summary of advantages and disadvantages of the author pays model is on bmi.com.

\section{Corrections and clarifications}

Acute treatment of moderate to severe depression with hypericum extract WS 5570 (St John's wort): randomised controlled double blind non-inferiority trial versus paroxetine

An editing error may have caused confusion in the abstract of this paper by A Szegedi and colleagues (BMJ 2005;330:503-6, 5 Mar). The initial daily dose of hypericum WS 5570 was $900 \mathrm{mg}$ split into three doses of $300 \mathrm{mg}$ - that is, $300 \mathrm{mg}$ three times a day.

NICE proposes to withdraw Alzheimer's drugs from NHS

In this News article by Zosia Kmietowicz we mistakenly referred to donepezil, rivastigmine, and galantamine as anticholinesterase inhibitors (BMJ 2005;330:495, 5 Mar). They are not; they are acetylcholinesterase inhibitors.

Children may die when left in overheated cars In this item in the "BMJ family highlights" section by Harvey Marcovitch, we wrongly said: "A few children were deliberately restrained in a safety belt so that adults could sleep, work, use drugs, or gamble" (BMJ 2005;330:564, 12 Mar). In fact, according to the original study, the children were restrained in a safety seat, not a belt.
Department of Clinical

Pharmacology, Radcliffe Infirmary, Oxford OX2 6HE Jeffrey K Aronson reader in clinical pharmacology

Jeffreyaronson@ clinpharm.ox.ac.uk 